最近はナノ繊維が実用化され, 学会誌を賑わせ, 研究 会も発足したと聞いているが，最近京都大学で開かれた 「ナノテク合同シンポジウム」ではナノ繊維が日本の優 位技術として紹介されており，今後ナノ䋊維は世界をリ ードする先端技術として大いに脚光を浴びることになる であろう。

\section{1. 宇宙への夢}

私は学会誌1993 年Vol.46.No.1に「宇宙を開き地球を 救う繊維夢物語」の一文を載せたが, その骨子は地球上 では作れない夢の繊維新素材を宇宙空間で合成実験を行 い, やがて宇宙工場，月面工場へと発展する夢物語であ
๖.

宇宙で作られる夢の繊維は鉄の3 倍の強度と高温, 低 温の耐熱性があり, 宇宙工場の建設資材や, 宇宙船の本 体, 砂漠緑化用素材に利用し, $\mathrm{CO}_{2}$ の吸収など環境改善 に利用できる優れものである.

今，まさに国際宇宙ステーションを宇宙で組み立て中 であり，日本の実験棟「きぼう」を宇宙飛行士土井さん が組み立てたが，その運用は日本の判断で行えることに なっている.

この実験棟で夢の未来繊維が誕生するという私の夢が 実現することを願って, 私のビジネス人生を充実させて いただいた日本繊維機械学会に感謝して拙文を結びたい.

\title{
染色現場における「色合わせ」の レベルアップについて
}

\section{谷本義雄 TANIMOTO Yoshio}

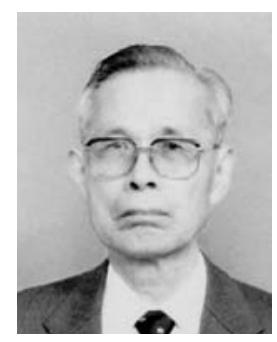

谷本義雄（たにもとよしお） 昭和 16 年, 桐生高等工業学校色染化学卒 業, 同年, 東洋紡績(株)入社, 昭和 49 年, 同社，定年退職，以降大阪府技術アドバイ ザーを委嘱される等中小染色企業の技術コ ンサルタントとして技術指導に従事, 現在 に至る.

繊維の染色分野で「染色指導」と称する仕事を永年や ってきたので，染色分野以外の方にはあまり関心のない ことかもしれないが, 染色のノウハウの最重要部分を占 める「色合わせ」について拙ない経験談を述べ本稿の責 任を果たさせて頂く.

およそ技術と称する限り必ず技術ノウハウというもの が存在することは言うまでもない.では染色の技術ノウ ハウとはどういうものかと聞かれるとあまりにも速と称 するものが多いので即答し兼ねるというのが本音ではな いかと思う.
それはさておき染色に限らず，いかなる分野でも必ず 結果が問われることは当たり前であるが，染色の場合は 目で見て結果がすぐに素人でもわかる場合がほとんどで あるので始末が悪い．殊に色が合わないということにな ると商取引の場合クレームの方便に使われることもあり， 当事者としては一番頭を痛める問題となる.

さて色が合わない原因の中で最も解決の難しい問題の 一つが染料の相溶性ということであるが，古くは Vickerstaff (I.C.I.社) が問題を提起して以来未だに解決さ れていない染色化学 (ないし染料化学) 分野の難問の一 つである.

染色技術者は，配合する染料のすべてが全く同じ性質 を持ち, あたかも一つの染料として繊維に染着するよう な染料を使用したいと考えている. そのような染料の組 み合わせが得られるならば染色処方の作成も容易になり, 染斑の発生もほとんど防止できるであろう。

近視眼的な見方かもしれないが，こうした問題に本気 で取り組む研究者はほとんど見られないように思う。 